\title{
Misuse of prescription drugs and other psychotropic substances among university students: a pilot study
}

\author{
Fahmi Fadhel ${ }^{1,2}$
}

${ }^{1}$ Psychology Department, College of Education, King Khalid University, Abha, Saudi Arabia (Correspondence to: Fahmi Fadhel fahmi4n@yahoo.com). ${ }^{2}$ Faculty of Arts, Hodeidah University, Al Hudaydah, Yemen.

\begin{abstract}
Background: Prescription drug abuse has emerged as the fastest growing problem globally. While people of all ages suffer from the harmful effects, the impact on the health of young people and their quality of life constitutes a significant public health problem.

Aims: To estimate the prevalence of the use of prescription drugs and other substances among university students

Methods: An online survey method was used. The tools were distributed in 2019 to 794 university students at Aden University in Yemen 48.2\% $(n=383)$ and King Khalid University in Saudi Arabia 51.8\% $(n=411)$. Students answered the Drug Abuse Screening Test (DAST-10), and a questionnaire on drug and substance abuse.

Results: The overall prevalence of low, moderate, substantial and severe on the DAST-10 scale was $27.2 \%, 10.5 \%, 2.1 \%$ and $0.8 \%$, respectively. The prevalence of sedative misuse among university students was high (12.5\%) and the differences between Yemeni and Saudi Arabian students in prescription drug and sedative misuse were significant. Female students were significantly lower than males on the DAST-10 scale. About 3\% of the Yemenis were abusing diazepam, while over 31\% of Saudi Arabians were abusing inhalants.
\end{abstract}

Conclusions: Our findings highlight the differences between university students in Yemen and Saudi Arabia misusing prescription stimulants and sedatives and the inhalation of volatile substances.

Keywords: non-medical drug use, prescription drugs, substance abuse, addiction, university students

Citation: Fadhel F. Misuse of prescription drugs and other psychotropic substances among university students: a pilot study. East Mediterr Health J. 2022;28(4):288-295. https://doi.org/10.26719/emhj.22.019

Received: 23/09/21; accepted: 24/10/21

Copyright (c) World Health Organization (WHO) 2022. Open Access. Some rights reserved. This work is available under the CC BY-NC-SA 3.0 IGO license (https://creativecommons.org/licenses/by-nc-sa/3.o/igo).

\section{Introduction}

The non-medical use of prescription drugs and substance abuse among university students is a complex, dangerous and widespread phenomenon $(1,2)$. It is a source of great concern in modern society (3). Prescription drug abuse has emerged as the fastest growing problem consuming globally expending huge efforts for control $(4,5)$. While people of all ages suffer from the harmful effects of the misuse of prescription substances, the impact on the health of young people and their quality of life constitutes a public health problem that has a significant impact on health and society (6), including instances of accidental death (5). Students who abuse prescription substances face many problems in terms of social relationships and may experience difficulty in thinking, attention and memory (7). In addition, the misuse of prescription substances has long-term effects and is associated with many risks, including poor health, quality of life (6) and sleep (8), as well as suicide, depression, personality disorders (9), economic and social burdens placed on the family and society and poor performance (10).

Modern society has an interest in protecting young people from the misuse of drugs and other psychotropic substances because they are the creative energy in society and are highly motivated to work for change and progress. Nowadays, prescribed stimulant abuse, nonmedical drug use and use of inhalants among young people, especially university students, has become a global public health concern: research is required in areas related to counselling, protection and treatment, including the development of knowledge of the misuse of prescription substances and the consequences.

There have been many assertions that we need accurate data to build prevention and treatment initiatives in modern communities (5). This is what stands behind many studies aimed at exploring the dangers of addiction and the prevalence of prescribed substances among university students. These studies seek to investigate factors attributable to misuse of prescription substances (11), such as the influence of the cultural or economic context. In this regard, it has been found that university students are the population that is most vulnerable to the risk of substance abuse and addiction-related problems. For example, Kounenou found that $4.7 \%$ of Greek university students used cannabis, $1.4 \%$ club drugs, $0.6 \%$ tranquillizers and $1.8 \%$ cocaine (3).

The high prevalence of prescription stimulant use among university students may be a result of to the influence of friends, lifestyle features at the university (2), and the fact that some students have the misconception 
that using prescription stimulants helps them improve their academic performance (12). The rate of nonmedical use of prescription stimulants among American university students has been reported as $18.8 \%$ (13), and in other research $62 \%$ of students reported that they had been offered a prescription enhancement at least once during their college lives (14), 6.7\% reported a current use of medical steroids, and $5.8 \%$ reported misuse in the past (15). In an Italian study, $11.3 \%$ of the university students reported non-medical use of cognitive enhancers, and this increased to $73.5 \%$ among students aged $18-22$ years (16). In another study from Italy, $74.7 \%$ said they used substances to improve cognitive function (17). In other studies, the proportion of students who used stimulant drugs was estimated to be $17 \%$ (18), and the non-medical use of prescription stimulants was $6.7 \%$ (15).

However, despite global prevention programmes and ongoing efforts to control the spread of non-medical use of prescription and other psychotropic substances, problems caused by the high rate of substance addiction among university students remain important issues in the Middle East and other developing countries (19). There are assertions that cultural aspects of the Middle East, such as smoking hookah and narghile, may lead to addiction to certain types of drugs $(19,20)$ and that the addiction of some young people to drugs belonging to the benzodiazepine group (especially diazepam) is the result of chewing khat, particularly in Yemen (21).

Therefore, understanding the deterioration in the situation regarding prescription substance abuse and its associated behaviours, including fundamental differences in how individuals behave during the phases of abuse, is important to predict the prevalence rates among university students (22) and to develop new intervention and response programmes. Unlike in many countries, there have been few epidemiological studies in Yemen and Saudi Arabia on the misuse of prescription and other psychotropic substances, particularly stimulants, among university students.

This study examines the prevalence of non-medical use of prescription stimulants and other substances abused by university students, including sedatives, overthe-counter medications and inhalants.

\section{Methodology}

\section{Sample}

The study sample consisted of 794 students at undergraduate level. They were randomly selected from 2 large universities: $48.2 \%(n=383)$ from the University of Aden (Yemen) and $51.8 \%(n=411)$ from King Khalid University (Saudi Arabia). We informed students that participation is voluntary, that their information is confidential, and that answering to the questionnaire was considered as expressed written consent.

The University of Aden in Yemen was chosen because it is far from military confrontations, and it is the second largest university in terms of numbers of students, faculties and academic programmes. While King Khalid University is ranked fifth largest among the universities in Saudi Arabia, it was chosen as it is the largest university in the southern region bordering Yemen, where there is a similarity between the citizens of the 2 countries in habits and traditions.

\section{Instruments}

The following tools were used in this study:

- The Drug Abuse Screening Test (DAST-10) (23) is a self-report measure of drug abuse assessment. The version of this test consists of 10 items, responded to with "yes" or "no." The final score ranges between 0-10 ( 0 = no problems reported, $1-2=$ low level, 3-5 = moderate level, 6-8 = substantial level, and 9-10 = severe level). The DAST-10 has been used in a number of previous studies and has been reported to have good psychometric properties.

- A questionnaire on drug and substances abuse was prepared by the researcher to assess the prevalence of the abuse of drugs and other psychotropic substances among university students. The initial form of the questionnaire was presented for review by mental health experts at the university. The final form of this questionnaire consisted of 18 items asking about the use of drugs and other substance abuse.

Demographic variables included age, sex, marital status, college, and year of study.

We would like to clarify that the tools used in this research cover drug use, non-medical use of drugs, such as diazepam, and the misuse of psychoactive substances, such as inhalants, tranquilizers and pain and fever relievers.

\section{Procedures}

This study was approved by the Deanship of Scientific Research of Aden University in Yemen (Ref 201/3/311) and King Khalid University in Saudi Arabia (Number 28423). All students gave written consent with the questionnaire, and all responses were anonymous.

The questionnaire was distributed by the administrative communications unit: 1380 students at the 2 universities were contacted via email and 794 responded, a response rate of $57.5 \%$. The study tools were applied before the end of the first semester, between 11 November and 18 December 2019.

The analysis was not pre-registered and thus the results should be considered exploratory.

\section{Results}

Of the 794 university students participating in the study, $46.6 \%(n=370)$ were female and $48.2 \%(n=383)$ were Yemeni (Table 1). They were distributed over 10 colleges, $42.4 \%$ ( $n=337$ ) from scientific colleges (medicine, business, engineering, science and computer) and 57.6\% ( $n=$ 457) from theoretical colleges (education, sharia and law, humanities, arts and community). 


\begin{tabular}{|c|c|c|c|c|c|c|}
\hline \multirow[t]{2}{*}{ Variable } & \multicolumn{2}{|c|}{$\begin{array}{l}\text { Yemen sample } \\
\quad(n=383)\end{array}$} & \multicolumn{2}{|c|}{$\begin{array}{l}\text { Saudi Arabian sample } \\
\qquad(n=411)\end{array}$} & \multicolumn{2}{|c|}{$\begin{array}{c}\text { Total } \\
(n=794)\end{array}$} \\
\hline & No. & $\%$ & No. & $\%$ & No. & $\%$ \\
\hline \multicolumn{7}{|l|}{ Sex } \\
\hline Male & 214 & 27.0 & 210 & 26.4 & 424 & 53.4 \\
\hline Female & 169 & 21.3 & 201 & 25.3 & 370 & 46.6 \\
\hline \multicolumn{7}{|l|}{ Marital status } \\
\hline Single & 337 & 42.4 & 379 & 47.7 & 716 & 90.2 \\
\hline Married & 42 & 5.3 & 27 & 3.4 & 69 & 8.7 \\
\hline Divorced/widowed & 4 & 0.5 & 5 & 0.6 & 9 & 1.1 \\
\hline \multirow[t]{2}{*}{ Age (years) } & Mean & SD & Mean & $\mathrm{SD}$ & \multirow{2}{*}{\multicolumn{2}{|c|}{$\begin{array}{l}t=2.791 \\
P=0.005\end{array}$}} \\
\hline & 21.76 & 2.78 & 21.25 & 2.33 & & \\
\hline
\end{tabular}

SD = standard deviation.

In this study, for DAST-10 Cronbach's alpha was 0.779, and 0.555 in split-half reliability (Spearman-Brown coefficient equal length $=0.714$ ); internal consistency was $0.549-0.648$ and all correlation coefficients were statistically significant $(P<0.05)$. For the drug and substances abuse questionnaire, Cronbach's alpha was 0.794 and split-half reliability was 0.423 (SpearmanBrown coefficient equal length $=0.594$ ); the internal consistency coefficients ranged between 0.212 and 0.616 and the correlation coefficients were statistically significant $(P<0.05)$.

Table 2 presents the prevalence rate of non-medical drug use among students with a comparison between students of the 2 countries. It is clear that the students who misuse prescription drugs, according to their assessment in the last 4-level scores of the DAST-10 (low, moderate, substantial, severe) had a percentage of $40.6 \%$, and the differences between the 2 countries in terms of the scale of drug use were statistically significant
$(P<0.05)$. There were also significant differences between Yemen and Saudi Arabian students in the total score of DAST-10 scale, as the mean of Yemeni students was higher than the Saudi Arabian students $(P<0.05)$.

The differences between male and female students on the DAST-10 scale are shown in Table 3: As per table 3. The differences between male and female students on the DAST-10 scale were significant (in the total sample only, not in the samples of Yemeni or Saudi Arabian students separately). There were more males than females at all severity levels of the DAST-10 scale, and the differences were significant at the 0.05 level.

In both countries, $12.5 \%(n=99)$ of students stated that they used sedatives without a medical requirement, and the differences between the 2 countries in misuse of sedatives was statistically significant $\left(\chi^{2} 43.71 ; P<0.05\right)$.

It was also found that $2.9 \%(n=11)$ of Yemeni students were taking diazepam with khat and that $31.4 \%(n=129)$ of Saudi Arabians enjoyed inhaling volatile substances.

Table 2 Prevalence of non-medical drug use among university students in Yemen and Saudi Arabia, 2019

\begin{tabular}{|c|c|c|c|c|c|c|}
\hline \multirow[t]{3}{*}{ DAST-10 cross tabulation } & \multicolumn{6}{|c|}{ Country } \\
\hline & \multicolumn{2}{|c|}{ Yemen } & \multicolumn{2}{|c|}{ Saudi Arabia } & \multicolumn{2}{|c|}{ Total } \\
\hline & No. & $\%$ & No. & $\%$ & No. & $\%$ \\
\hline \multicolumn{7}{|l|}{ DAST-10 } \\
\hline No problems & 203 & 25.6 & 269 & 33.9 & 472 & 59.5 \\
\hline Low & 119 & 15.0 & 97 & 12.2 & 216 & 27.2 \\
\hline Moderate & 51 & 6.4 & 32 & 4.0 & 83 & 10.5 \\
\hline Substantial & 8 & 1.0 & 9 & 1.1 & 17 & 2.1 \\
\hline Severe & 2 & 0.3 & 4 & 0.5 & 6 & 0.8 \\
\hline \multirow[t]{3}{*}{ Total } & 383 & 48.2 & 411 & 51.8 & 794 & 100.0 \\
\hline & \multicolumn{2}{|c|}{$\chi^{2}=15.58$} & \multicolumn{2}{|c|}{$\mathrm{Df}=4$} & \multicolumn{2}{|c|}{$P=0.004$} \\
\hline & Mean & SD & Mean & SD & $\mathbf{t}$ & $\mathbf{P}$ \\
\hline \multirow[t]{2}{*}{ Total DAST-10 score } & 1.1514 & 1.699 & 0.8443 & 1.697 & 2.546 & 0.011 \\
\hline & No. & $\%$ & No. & $\%$ & No. & $\%$ \\
\hline Sedatives abuse & 17 & 2.1 & 82 & 10.3 & 99 & 12.5 \\
\hline
\end{tabular}




\begin{tabular}{|c|c|c|c|c|c|c|}
\hline \multirow[t]{2}{*}{ Sex } & \multicolumn{5}{|c|}{ DAST-10 level (no. of students) } & \multirow[t]{2}{*}{ Total } \\
\hline & No problems & Low & Moderate & Substantial & Severe & \\
\hline Male & 236 & 124 & 45 & 13 & 6 & 424 \\
\hline Female & 222 & 106 & 38 & 4 & 0 & 370 \\
\hline \multirow[t]{2}{*}{ Total } & 458 & 230 & 83 & 17 & 6 & 794 \\
\hline & \multicolumn{6}{|c|}{$\chi^{2} 9.563 ; P<0.05$} \\
\hline
\end{tabular}

\section{Discussion}

The current study is among the first to examine the prevalence of non-medical use of prescription drugs and other substances among university students in Saudi Arabian Arabia and Yemen. And the results indicated the existence of high rates of prescription drug abuse among university students in 2 countries. The students' grades were distributed at the 5 levels in the DAST-10 differently, more than half were at level 1 (no problems) and more than a quarter were on level 2 (low). At these levels psychiatrists do not recommend any need for treatment for addiction; rather, they advise psychological counselling to address the misuse of medications (24).

Just over $10 \%$ of the participants stated a moderate level of non-medical drug use on the DAST-10 scale. This is considered a risk indicator that should concern parents and psychotherapists as students who receive this assessment may develop worsening problems and prescription drug abuse is evaluated as risky behaviour at this level (24). On the other hand, in our participants, prevalence rates were low at the substantial level and very low at the severe level.

According to the National Drug Prevention Project in Saudi Arabia, the prevalence of psychotropic substance use was reported at $17.7 \%$ in residential neighbourhoods where students live, $8.2 \%$ in their relatives, $8.3 \%$ in the student environment, and the prevalence of psychotropic substances use among students' friends ranges between $6.8 \%$ and $10.9 \%(25)$.

Our results are consistent with a number of studies which indicated a high prevalence of non-medical drug abuse among students $(26,27)$. Brandt et al. investigated the prevalence of prescription drugs among university students and they found a high prevalence of using prescription medications for non-medical purposes, e.g. painkillers, stimulants and anti-anxiety medication (26).

While our findings differed from those of some other studies that found low prevalence of non-medical drug use among college students $(28,5)$, Jia et al. reviewed drug prevalence studies among students in China from 2004 to 2013 and found that the prevalence rate of the use of sedatives (hypnotics) in students was $6.10 \%(28)$.

Additionally, the statistical analysis revealed significant differences between students of the 2 countries in terms of taking prescription drugs for non-medical purposes. Common explanations include poverty and cultur$\mathrm{al}$ and social factors causing increases in substance use
$(29,22)$. Yemen is classified among the poor countries and Saudi Arabia is among the rich countries; these economic differences play an important role in the differences between the populations in financial capabilities. In this regard, a report on high school students in Italy found an association between drug use and high socioeconomic level, low academic achievement, high rates of school failure and impairment in terms of social coping. (31).

Environmental and cultural influences may differently affect males and females and how they respond to prescription drugs abuse and to treatment programmes (30). Our findings showed significant differences between male and female students; males were more likely to use prescription drugs than females. These differences can be explained by the fact that society imposes many restrictions on female mobility compared to males, who obtain a lot of independence and freedom of action. Some research indicates that addiction is both a biological and cultural phenomenon (30), and has demonstrated that addiction and its consequences differ according to sex $(32,33)$. The interactions between biological, social, cultur$\mathrm{al}$, environmental, and developmental influences result in gender differences and these can influence reactions to this phenomenon (30). Our results are consistent with the results of Wagner et al., who found significant gender differences in drug use, with men showing a significant increase over women in using tobacco, marijuana, and hallucinogens (34). In a multi-country cross-sectional study among university students in south-east Asian countries, Yi et al. found significant differences between males and females in illicit drug use. Male students were "significantly more likely to be ever users compared to females" (35).

One of the primary goals of this study was to examine the prevalence of sedative abuse among university students. The results showed that the prevalence rate was more than $12 \%$ in the 2 countries and this was statistically significantly higher among Saudi Arabian students. Among Yemenis, the prevalence of the misuse of diazepam while chewing khat was low - a level that may not reveal the true extent of the problem as perceived by the local media, but sufficient to serve as a risk indicator based on accurate scientific data.

The high sedative abuse rates among university students may be attributed to the misconception among many young people that prescribed drugs are safer alternatives to other, illegal drugs $(36,37)$. University students might use sedatives to reduce feelings of tension 
or to cope with stress or anxiety (27). Daily, university students are exposed to fatigue, exhaustion, stress and anxiety, which lessens their ability to meet academic demands. Consequently, they may search for substances that will help them. The differences between countries in the use of sedatives may be due to the availability of other alternatives for Yemeni students such as chewing khat, while this option is not available for Saudi Arabian students. This highlights the role of cultural factors in this case.

Our results revealed a high prevalence rate of inhalant misuse among Saudi Arabian students: one third of them reported that they enjoy inhaling paints and other chemicals. This is a large and worrying proportion that should prompt appropriate preventive action among agencies concerned with combating substance addiction. There have been few studies in the Middle East on the abuse of sedatives or inhalants. In Lebanon, one study revealed a high prevalence of the non-medical use of sedatives, especially pain relievers (15.1\%), among students in the American University of Beirut (20). A study in Sudan found a high prevalence (31\%) of substance abuse; current prevalence of the use of cannabis, alcohol, amphetamines, tranquilizers, inhalants, opiates, cocaine and heroin was $4.9 \%, 2.7 \%, 2.4 \%, 3.2 \%, 1 \%, 1.2 \%, 0.7 \%$, and $0.5 \%$, respectively (38). Yi et al. found significant differences in drug use between students in low-middleincome countries and middle-high-income countries; drug use was lower among students from lower-middleincome countries than among students from middlehigh-income countries or high-income countries (35).
It is clear from the results of the current study that the prevalence of prescription drug and substance use in university life constitutes a threat to the educational policies that countries pursue to protect young people and make the most of their energies. Due to these challenges. The authorities in both Yemen and Saudi Arabia must develop new policies to deal with such problems.

This study has certain limitations. The respondents might not be representative of all students in the Aden and King Khaled Universities owing to the employment of an online survey method.

A second limitations was that prescription stimulants and substance abuse were self-reported. Students might not disclose their use of drugs or substances abuse, which exposes this study method to the limitations of all selfreported surveys (37). Therefore, the data may not indicate accurate estimates of the problem and its findings cannot be considered illustrative of all students in the 2 universities or of other universities in Saudi Arabia and Yemen. Nevertheless, the responses of the students participating in the study include valid calculations for those who reported non-medical use of prescribed drugs or inhalants as described in the questionnaire and DAST10.

\section{Conclusions}

The results of this study should be considered in planning intervention programmes to reduce the use of prescription stimulants and other substances among university students. We suggest developing specific strategies to combat, control and mitigate the use of prescription stimulants and other substances among college students.

\section{Acknowledgment}

I am grateful to Professor Dr Kay M Mach for proofreading and editing this article.

Funding: None

Competing interests: None declared.

\section{Usage abusif de médicaments soumis à prescription et d'autres substances psychotropes parmi les étudiants universitaires : étude pilote \\ Résumé}

Contexte : L'abus de médicaments soumis à prescription est aujourd'hui le problème qui connaît la croissance la plus rapide au niveau mondial. Les effets néfastes de ce phénomène touchent des personnes de tous âges, mais l'impact sur la santé des jeunes et leur qualité de vie constitue un important problème de santé publique.

Objectifs : Estimer la prévalence de l'usage abusif de médicaments soumis à prescription et d'autres substances parmi les étudiants universitaires.

Méthodes: Une méthode d'enquête en ligne a été utilisée. Les outils ont été distribués en 2019 à 794 étudiants de l'Université d'Aden au Yémen à hauteur de 48,2\% $(n=383)$ et de l'Université King Khalid en Arabie saoudite à hauteur de $51,8 \%(n=411)$. Les étudiants ont répondu au test de dépistage de l'abus de drogues (DAST-10), ainsi qu'à un questionnaire sur l'abus de drogues et de substances.

Résultats: La prévalence globale des scores bas, modérés, substantiels et sévères sur l'échelle DAST-10 était respectivement de $27,2 \%, 10,5 \%, 2,1 \%$ et $0,8 \%$. La prévalence de l'usage abusif des sédatifs parmi les étudiants 
universitaires était élevée (12,5\%) et les différences entre les étudiants yéménites et saoudiens en matière d'utilisation abusive des médicaments et des sédatifs soumis à prescription étaient considérables. Les étudiantes étaient significativement moins nombreuses que les étudiants sur l'échelle DAST-10. Près de $3 \%$ des Yéménites abusaient du diazépam, tandis que plus de 31 \% des Saoudiens consommaient de façon abusive des substances inhalées.

Conclusions: Nos résultats mettent en évidence les différences entre les étudiants universitaires du Yémen et de l'Arabie saoudite qui font un usage abusif de stimulants et de sédatifs soumis à prescription et qui inhalent des substances volatiles.

$$
\text { إسهاءة استعال الأدوية الموصوفة طبيَّا وغيرها من المواد المؤثرة على العقل في صفوف الطلاب الجامعيين: دراسة رائدة }
$$

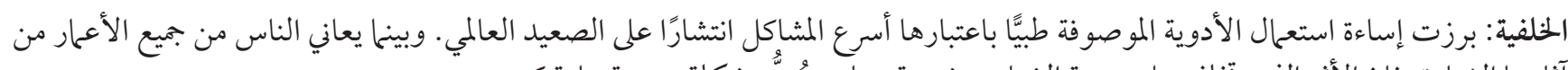

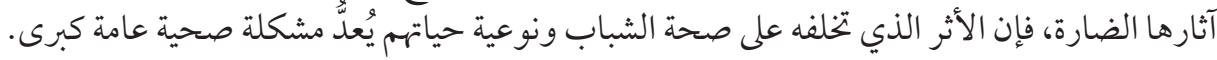
الأهداف: هدفت هذه الدراسة الى تقدير مدى انتشار استعمال الأدوية الموصوفة طبيًّا، وغيرها من المواد في صفوف الطلاب الجامعيين

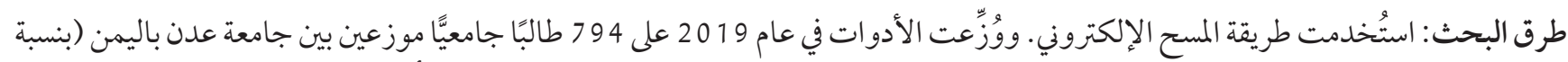

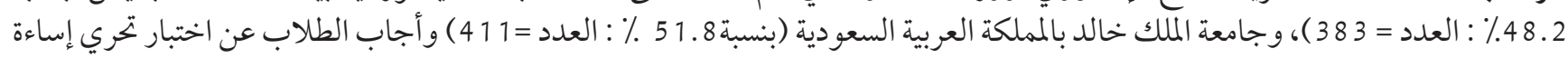

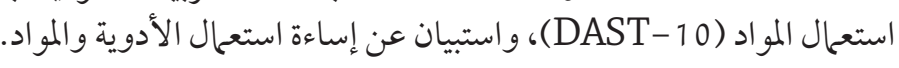

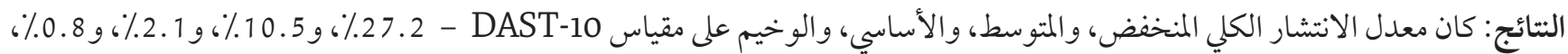

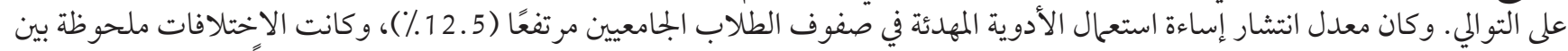

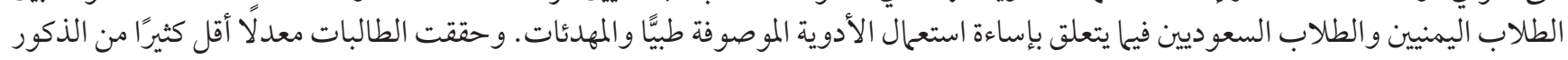

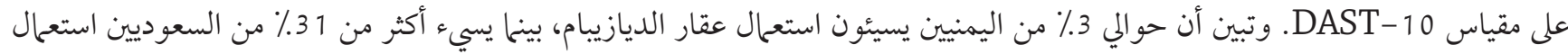
المستنشقات.

الاستنتاجات: تسلط النتائج التي توصلنا إليها الضوء على الاختلافات بين طلاب الجامعات في اليمن والمملكة العربية السعودية، ممن يسيئون

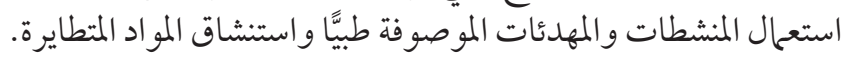

\section{References}

1. Taking the hit: student drug use and how institutions respond. London: NUS Connect; 2018 (https://www.nusconnect.org.uk/ resources/taking-the-hit-student-drug-use-and-how-institutions-respond, accessed 24 November 2021).

2. Bennett T, Holloway K. Motives for illicit prescription drug use among university students: A systematic review and meta-analysis. Int J Drug Policy. 2017 Jun;44:12-22. doi:10.1016/j.drugpo.2017.02.012

3. Kounenou, K. Drug use by Greek university students and preventive actions. Procedia Social Behav Sci. 2011;15:456-60. doi:10.1016/j.sbspro.2011.03.121

4. Phillips J. Prescription drug abuse: Problem, policies, and implications. Nurs Outlook. 2013;61(2):78-84. doi:10.1016/j.outlook.2012.06.009

5. Paul ABM, Simms L, Mahesan AA, Belanger EC. Teens, drugs, \& Vegas: toxicological surveillance of illicit prescription and illegal drug abuse in adolescents (12-17 years) using post-mortem data in Clark County, Nevada from 2005 to 2015. J Forensic Leg Med. 2018 Aug;58:20-4. doi:10.1016/j.jflm.2018.04.002

6. Kounenou, K. Exploration of the relationship among drug use \& alcohol drinking, entertainment activities and self-esteem in Greek University students. Procedia Social Behavior Sci. 2010;2:1906-10. doi:10.1016/j.sbspro.2010.03.1007

7. Ibrahim HA, Mahmud S, Abubakar A, Harazimi CA, Abdulkadir S. Effect of drug abuse among youth and its impact on learning. IOSR J Pharm Biol Sci. 2016;11(1):14-7. doi:10.9790/3008-11131417

8. Fadhel FH. Exploring the relationship of sleep quality with drug use and substance abuse among university students: a cross-cultural study. Middle East Curr Psychiatry. 2020;27(65):1-9. doi:10.1186/s43045-020-00072-7

9. Griffin KW, Lowe SR, Acevedo BP, Botvin GJ. Affective self-regulation trajectories during secondary school predict substance use among urban minority young adults. J Child Adolesc Subst Abuse. 2015; 24(4):228-234. doi:10.080/1067828X.2013.812530

10. Grant BF, Saha TD, Ruan WJ, Goldstein RB, Chou SP, Jung J, et al. Epidemiology of DSM-5 drug use disorder: results from the National Epidemiologic Survey on Alcohol and Related Conditions-III. JAMA Psychiatry. 2016;73(1):39-47. doi:10.1001/jamapsychiatry.2015.2132 
11. Kokkevi AE, Arapaki AA, Richardson C, Florescu S, Kuzman M, Stergar E. Further investigation of psychological and environmental correlates of substance use in adolescence in six European countries. Drug Alcohol Depend. 2007 May 11;88(2-3):308-12. doi:10.1016/j.drugalcdep.2006.10.004

12. Arria AM, Geisner IM, Cimini MD, Kilmer JR, Caldeira KM, Barrall AL, et al. Perceived academic benefit is associated with nonmedical prescription stimulant use among college students. Addict Behav. 2018 Jan;76:27-33. doi:10.1016/j.addbeh.2017.07.013

13. Munro BA, Weyandt LL, Marraccini ME, Oster DR. The relationship between nonmedical use of prescription stimulants, executive functioning and academic outcomes. Addict Behav. 2017;65:250-7. doi:10.1016/j.addbeh.2016.08.023

14. Garnier-Dykstra LM, Caldeira KM, Vincent KB, O'Grady KE, Arria AM. Nonmedical use of prescription stimulants during college: four-year trends in exposure opportunity, use, motives, and sources. J Am Coll Health. 2012;60(3):226-34. doi:10.1080/07448 481.2011.589876

15. Grant JE, Redden SA, Lust K, Chamberlain SR. Nonmedical use of stimulants is associated with riskier sexual practices and other forms of impulsivity. J Addict Med. 2018 Nov/Dec;12(6):474-480. doi:10.1097/ADM.0000000000000448

16. Majori S, Gazzani D, Pilati S, Paiano J, Sannino A, Ferrari S, et al. Brain doping: stimulants use and misuse among a sample of Italian college students. J Prev Med Hyg. 2017 Jun;58(2):E130-E140. PMID: 28900353

17. Pighi M, Pontoni G, Sinisi A, Ferrari S, Mattei G, Pingani L, et al. Use and propensity to use substances as cognitive enhancers in Italian medical students. Brain Sci. 2018 Nov 9;8(11):197. doi:10.3390/brainsci8110197

18. Benson K, Flory K, Humphreys KL, Lee SS. Misuse of stimulant medication among college students: a comprehensive review and meta-analysis. Clin Child Fam Psychol Rev. 2015 Mar;18(1):50-76. doi:10.1007/s10567-014-0177-z

19. Bejjani N, El Bcheraoui C, Adib SM. The social context of tobacco products use among adolescents in Lebanon (MedSPAD-Lebanon). J Epidemiol Glob Health. 2012 Mar;2(1):15-22. doi:10.1016/j.jegh.2012.02.001

20. Ghandour LA, El Sayed DS, Martins SS. Prevalence and patterns of commonly abused psychoactive prescription drugs in a sample of university students from Lebanon: an opportunity for cross-cultural comparisons. Drug Alcohol Depend. 2012 Feb 1;121(1-2):110-7. doi:10.1016/j.drugalcdep.2011.08.021.

21. Al-Hakim I. [Yemen: drug crossing gateway to the region]. Mareb Press newspaper. 2007, April 20 (https://marebpress.net/articles.php?id=1593, accessed 10 December 2019) (in Arabic).

22. Riley AL, Hempel BJ, Clasen MM. Sex as a biological variable: Drug use and abuse. Physiol Behav. 2018 Apr 1;187:79-96. doi:10.1016/j.physbeh.2017.10.005

23. Skinner HA. The drug abuse screening test. Addict Behav. 1982;7(4):363-371. doi:10.1016/0306-4603(82)90005-3

24. Yudko E, Lozhkina O, Fouts A. A comprehensive review of the psychometric properties of the Drug Abuse Screening Test. J Subst Abuse Treat. 2007 Mar;32(2):189-98. doi:10.1016/j.jsat.2006.08.002

25. NDPP. [Prevention of drug use and psychotropic substances between theory and practice.] (in Arabic). Riyadh: National Anti-Drug Committee, Ministry of Interior; 2016 (http://arabci.org/Articles?id=45309, accessed 14 November 2020).

26. Brandt SA, Taverna EC, Hallock RM. A survey of nonmedical use of tranquilizers, stimulants, and pain relievers among college students: patterns of use among users and factors related to abstinence in non-users. Drug Alcohol Depend. 2014 Oct 1;143:272-6. doi:10.1016/j.drugalcdep.2014.07.034

27. Kasperski SJ, Vincent KB, Caldeira KM, Garnier-Dykstra LM, O'Grady KE, Arria AM. College students' use of cocaine: results from a longitudinal study. Addict Behav. 2011 Apr;36(4):408-11. doi:10.1016/j.addbeh.2010.12.002

28. Jia Z, Jin Y, Zhang L, Wang Z, Lu Z. Prevalence of drug use among students in mainland China: A systematic review and meta-analysis for 2003-2013. Drug Alcohol Depend. 2018 May 1;186:201-206. doi:10.1016/j.drugalcdep.2017.12.047

29. Nalven T, Spillane NS, Schick MR. Risk and protective factors for opioid misuse in American Indian adolescents. Drug Alcohol Depend. 2020 Jan 1;206:107736. doi:10.1016/j.drugalcdep.2019.107736

30. Becker JB, McClellan ML, Reed BG. Sex differences, gender and addiction. J Neurosci Res. 2017 Jan 2;95(1-2):136-147. doi:10.1002/ jnr.23963

31. Gerra G. Zaimovic A, Rizzi O, Timpano M, Zambelli U. Substance abuse among secondary-school students and its relationship with social coping and temperament. Bull Narcotics. 1999;LI(1-2):75-96 (https://www.unodc.org/unodc/en/data-and-analysis/ bulletin/bulletin_1999-01-01_1_pageo07.html, accessed 26 November 2021).

32. Becker JB, McClellan M, Reed BG. Sociocultural context for sex differences in addiction. Addict Biol. 2016 Sep;21(5):1052-9. doi:10.1111/adb.12383

33. Becker JB, Hu M. Sex differences in drug abuse. Front Neuroendocrinol. 2008 Jan;29(1):36-47. doi:10.1016/j.yfrne.2007.07.003

34. Wagner GA, Stempliuk Vde A, Zilberman ML, Barroso LP, Andrade AG. Alcohol and drug use among university students: gender differences. Braz J Psychiatry. 2007 Jun;29(2):123-9. doi:10.1590/s1516-4446200600500003

35. Yi S, Peltzer K, Pengpid S, Susilowati IH. Prevalence and associated factors of illicit drug use among university students in the association of southeast Asian nations (ASEAN). Subst Abuse Treat Prev Policy. 2017 Apr 6;12(1):9. doi:10.1186/s13011-017-0096-3

36. The non-medical use of prescription drugs: policy direction issues. Vienna: United Nations Office on Drugs and Crime; 2011 (https://www.unodc.org/documents/drug-prevention-and-treatment/nonmedical-use-prescription-drugs.pdf, accessed 24 November 2021). 
37. Holloway KR, Bennett TH, Parry O, Gorden C. Characteristics and consequences of prescription drug misuse among university students in the United Kingdom. J Subst Use. 2014;19(1-2):156-63. doi:10.3109/14659891.2013.765513

38. Osman T, Victor C, Abdulmoneim A, Mohammed H, Abdalla F, Ahmed A, et al. Epidemiology of substance use among university students in Sudan. J Addict. 2016;1-8. doi:10.1155/2016/2476164 